\title{
Energy Management in Energy-Intensive Industries: Developing a Conceptual Map
}

\author{
Vilson Roiz Gonçalves Rabelo da Silva ${ }^{1^{*}}$ \\ https://orcid.org/0000-0002-2660-9717
}

Eduardo de Freitas Rocha Loures ${ }^{2^{*}}$
https://orcid.org/0000-0002-1963-6186

Edson Pinheiro de Lima ${ }^{2^{*}}$

https://orcid.org/0000-0001-9331-1569

\author{
Sergio Eduardo Gouvêa da Costa ${ }^{2^{\star}}$ \\ https://orcid.org/0000-0001-7409-9216 \\ ${ }^{1}$ Federal University of Paraná (UFPR), Electrical Engineering Department, Curitiba, Paraná, Brazil; \\ ${ }^{2}$ Pontifical Catholic University of Paraná (PUC-PR), Industrial and Systems Engineering Department, \\ Curitiba, Paraná, Brazil;
}

Received: 2018.11.05; Accepted: 2019.07.26.

* Correspondence: vilroiz@eletrica.ufpr.br (VS); eduardo.loures@pucpr.br (EL); e.pinheiro@pucpr.br (EL); s.gouvea@pucpr.br (SC)

\section{HIGHLIGHTS}

- ISO 50001-based conceptual map for energy management in energy-intensive industries

- Research breakdown of an Energy Management System, under a process design proposition

- Description of the successful practices carried out in the industry and cited in the literature

\begin{abstract}
This paper presents the development of a conceptual map regarding energy management applied to industry. The energy issue is currently of great relevance, especially for the so-called energy-intensive industries related to high energy consumption and their associated environmental impacts. The present research is characterized as a basic, exploratory approach justified by the need to build knowledge on the subject of energy management in industry. The methodology provides for the use of a computational tool called CMap Tools, which assists in the graphic representation of the proposed conceptual map. The conceptual map based on the ISO 50001 standard and on successful energy management practices described in the scientific literature is directed toward a process design covered by the managerial discipline called Business Process Management. The conceptual map is intended to clarify the relationships that are established between the intra-organizational and main external stakeholders involved in an energy management system. Owing to the way internal areas and external organizations relate, the representation structure using a "Spider" is the most appropriate. The work developed presents an energy management system for an energy-intensive industry in a clear
\end{abstract}


(conceptually and visually), orderly, unified, harmonious, and balanced manner indicating the distribution of its elements, and serves as an initial step in the creation of an ontology for this area of knowledge.

Keywords: energy management system, energy-intensive industries, conceptual map.

\section{INTRODUCTION}

Economic, environmental, and energy issues have driven industries to adopt new practices and better energy management. The companies aim to reduce costs, gain competitiveness, and meet the wishes of consumers and stakeholders by presenting a friendly image regarding environmental issues and the sustainability of the planet.

Energy-intensive industries (EII) (cement, iron and steel, pulp and paper, petrochemical, chemical, aluminum, and glass) are large sectors playing significant roles in the development of any country. However, they are associated with high energy consumption and can have major environmental impact.

The energy referred to in this research is considered in its various forms, such as electricity, fuel, steam, heat, compressed air, and other analogous forms that can be purchased, stored, processed, used in equipment or in a process, or recovered.

Energy management is a relatively new and little explored interdisciplinary field of knowledge that focuses on organizational aspects rather than on the more popular studies regarding system improvements and technological aspects related to energy efficiency.

The difficulties described in the scientific literature for successful energy management in industry are in the form of barriers and their origins: (i) external, such as market, government/politics, suppliers, technology/services, designers, manufacturers, energy suppliers, and financiers; and (ii) intra-organizational: from an economic-behavioral and organizational perspective.

Regarding the intra-organizational barriers, different aspects stand out: (i) lack of effective internal management in the company; (ii) complex decision-making chains; (iii) lack of power and influence of an energy manager; (iv) organizational culture leading to neglect of energy and environmental aspects; (v) low importance given to the energy efficiency program (not the main business of the company) [1-6].

Recently, the energy management standard ABNT NBR ISO 50001: 2011 Energy Management Systems - Requirements with Guidance for Use [7] was introduced, which provides guidelines and specifies requirements for the establishment, implementation, maintenance, and improvement of an energy management system. In addition, there is a track record dating back to the 1980s of some successful industry energy management initiatives and practices that should be evaluated.

The need to create a conceptual map arises from the desire to bring together the requirements of the international standard ISO 50001 with the initiatives and the successful practices carried out in industry and described in the scientific literature to allow a better understanding and to allow the granular analysis of energy management in industry. For our purposes, we consider the Brazilian energy industry. The map is also being presented as a research breakdown on an Energy Management System (EnMS) in Ell and to propose a process design under the management discipline called Business Process Management (BPM).

\section{METHODOLOGY}

The present research is characterized as a basic, exploratory approach justified by the need to build knowledge regarding energy management in industry. The methodology utilizes a computational tool called CMap Tools, which assists in the graphic representation of the proposed conceptual map. The conceptual map is based on a process design for EnMS based on the ISO50001 standard, also taking into account the good practices mentioned in the scientific literature. The specific objectives are to: (i) describe the basic diagram of an EnMS meeting the requirements of ISO 50001 successful practices for energy management and process design; (ii) analyze and categorize the data transfer from an 
EnMS to the Ell; and (iii) develop a conceptual map of an energy management system, explaining the relationships among the main stakeholders.

\section{Foundation}

The objective of an EnMS is to enable organizations to establish the systems and processes necessary to improve energy performance, including energy efficiency and energy consumption. With respect to the organizational barriers previously mentioned, they can be better studied and understood using an enterprise engineering (EE) approach.

In previous studies [8], a process design proposal for an EnMS in Ell was carried out according to the management discipline called Business Process Management (BPM).

Thus, as guides and fundamentals, the following points are considered: (i) the need to gather and facilitate the visualization and understanding of the requirements of ISO 50001; (ii) incorporate successful energy management initiatives and practices already carried out in industry and described in the scientific literature; and (iii) develop the process design for the energy management system, which indicate the need to develop a conceptual map. The purpose of the conceptual map is to identify and make explicit the relationships among the main actors involved in the implementation of an EnMS in Ell.

\section{Conceptual Map}

Conceptual maps are hierarchical structures represented graphically, presenting a set of interrelated concepts. Through this type of structure, it is possible to emphasize the most important relationships among these concepts [9,10]. As graphical representations, conceptual maps indicate the relationships among concepts that are connected through keywords. Concepts are enclosed in boxes (or other geometric shapes), and lines link concepts by means of connecting words or phrases. It is recommended that the conceptual map be drawn after an idea matures.

\section{Construction of Conceptual Maps}

The construction of a conceptual map involves the identification of the concepts or ideas belonging to a subject and the descriptions of the relationships among these ideas in the form of a schematic drawing [9].

The concepts must be related in a coherent manner (according to a logical order), and the words or phrases used to relate these concepts should allow the construction of sentences with logical and propositional meaning. Thus, the structure of the conceptual map will allow efficient exploration of all existing relationships among concepts. Common phrases used to relate concepts in conceptual maps are it is composed of, depends on, is influenced by, includes, and causes, among others [9].

There are different types of conceptual maps, which can be classified according to their basic structure or presentation form. The structural classifications for conceptual maps are:

Spider structure: Organizes the information in a radial manner, where the main theme is placed in the center of the map;

Hierarchical structure: Presents the information in hierarchical order, according to the level of importance of the concepts (the most relevant information is placed at the beginning of the hierarchical chain);

Flowchart structure: Organizes information in a linear format, ordering the concepts in a logical sequence (similar to a book);

Systems Structure: Organizes the information in the form of a flow chart, allowing the possibility of insertion and exclusion of concepts.

Regarding the presentation form, conceptual maps can be classified as:

Landscape: Used in situations where there is a need to present the information in panoramic context; 
$3 D$ (multidimensional): Presents the relationships among concepts in three-dimensional form. It allows representing and exploring relationships not observed using conceptual maps in two dimensions;

Mandala: Presents the information in geometric format, providing a visual effect that allows representation of the thought processes of individuals.

\section{Computational Tools for Conceptual Maps}

Maintenance computational tools (software) are used to create conceptual maps in their various forms. Such tools allow conceptual maps to be designed quickly and intuitively. Among the conceptual map tools currently available in the market, the following stand out:

CMap Tools: Free software developed by the Institute for Human Machine Cognition of the University of West Florida under the supervision of Dr. Alberto J. Cañas, expert in this field of knowledge. It provides applications for the elaboration and graphical representation of conceptual maps. Because it is free and widely used in the academic world, it was the software adopted for the elaboration of the conceptual map in this work;

Inspiration: Developed by Inspiration Software, it is similar to CMap Tools, but you must purchase a license to use it $[10,11]$;

MindMeister: Online tool used in the elaboration of conceptual maps. It offers free and paid versions, according to the application and the user profile [12].

\section{DEVELOPMENT OF THE CONCEPTUAL MAP FOR THE EnMS}

\section{Description of the Basic Diagram}

The design of an energy management process in the BPM dimension applied in the EII based on the ISO50001 standard and good practices described in the scientific literature, requires characterizing the main actors involved, that is, the internal functional areas and external organizations (the stakeholders).

The internally selected actors are the functional areas that have the greatest contribution, affinity, and involvement with the energy management process. They are: (i) Top Management - TM (board of directors); (ii) Energy Management Team (EnMT)/ energy manager, (iii) engineering; (iv) maintenance; (v) production; and (vi) administration. Also identified are companies such as electric power and gas utilities, electric energy traders, and Energy Service Companies (ESCO). The areas defined as Top Management - TM (board of directors) and Energy Management Team (EnMT)/ energy manager are propositions formulated by ISO 50001.

The external organizations and internal functional areas were categorized and represented according to their hierarchical level regarding their role in energy management (clockwise from the functional area top management), as shown in Figure 1.

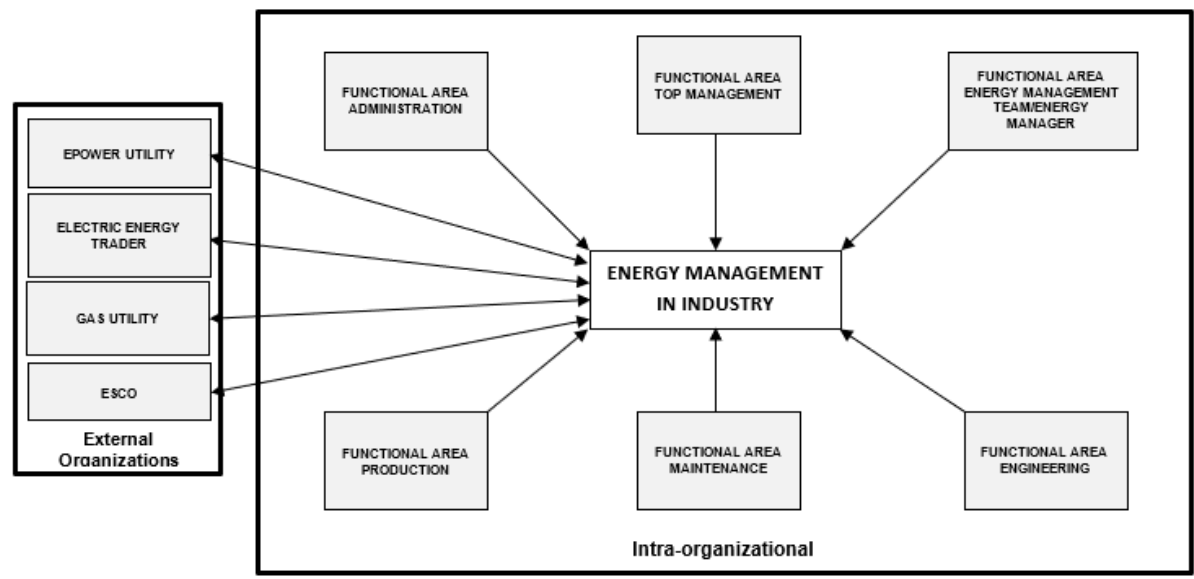

Figure 1. General Representation of Functional Areas for the Proposed Energy Management System. Source: The Author. 


\section{Data Analysis and Categorization}

The analysis and categorization of the data that make up the conceptual map of energy management in the Ell were carried out following the concepts of the energy management process mentioned above by describing the main actors in an arrangement according to external organizations and internal functional areas (intra-organizational).

Concepts concerning organizations external to the intra-organizational functional areas will be described in detail below, and the complete conceptual map is presented in Figure 4 of Appendix $\mathrm{A}$ of this paper.

\section{External Organizations}

The external organizations involved in the EnMS proposed by [8] for the composition of the energy management model for Ell and included in the conceptual map are listed below [7,13-15]:

Electric power utility: Federal public service agent, delegated by grants through bidding. It can be a generator, distributor, or transmitter of electric energy [16]. When it acts as an electric energy distributor, it is responsible for establishing the physical connections between energy consumers and the electric system;

Gas utility: Federal public service agent, delegated by grants through a bidding process. It explores the public service of piped natural gas supply for industries, residences, commercial establishments, and vehicles.

Electric energy trader: These are legal entities that buy and sell electric energy to concessionaires, authorized distributors, or free consumers [16]. Unlike generation agents, marketers do not have plants that produce electricity; they acquire electricity from different suppliers to offer a diversified portfolio of products to their consumers, reducing transaction costs, and consequently promoting efficient relationships between generators and consumers of electricity. Therefore, the marketer acts by managing volume and price risk for both generators and consumers in a free energy market. The free contracting environment is the segment of the market in which electric energy purchases and sales are carried out, subject to bilateral contracts freely negotiated according to specific marketing rules and procedures. Although they do not have generation assets, the trading operations are heavily regulated by Brazil's ANEEL agency [17];

ESCO (Energy Services Company): A type of engineering firm that specializes in energy conservation services in its various forms (electrical, thermal), which may also include utilities such as water and gas [18]. Its main function is to promote energy efficiency at its clients' premises [15]. ESCOs serve the most diverse market segments (public, industrial, commercial, and residential), acting in the development of energy efficiency and emission reduction projects, as well as in the installation and maintenance of equipment and in the monitoring and verification of the energy economy generated by these actions [19]. Among the various activities that can be carried out by an ESCO, it is important to highlight the energy review (to either carry out or assist in its realization) to quantify the energy consumption of an industry and to identify energy efficiency opportunities in order to reduce expenses and improve the performance of a plant [14]. ESCOs can also develop activities in the form of performance contracts (modality "no cure, no pay"), where an ESCO is paid based on a percentage (defined in the contract) of the energy economy generated by the energy efficiency actions applied to an organization [20].

Depending on the type of industry addressed, the external organizations involved in the EnMS may undergo changes, especially with regard to utilities such as gas.

\section{Intra-organizational: Functional Areas}

The areas within an organization are the main actors involved in the EnMS. Culturally, Brazilian industries are internally divided into functional areas (FA), whose roles and responsibilities are well defined within organizations. To properly apply the proposed model to organizations with other types of internal divisions, adaptations would be required. The priority assignment of each functional area is presented according to the area's importance 
level (from highest to lowest importance) and according to the order of precedence of the actions during the implementation and conduction of the EnMS.

\section{Intra-organizational: FA Top Management (TM)}

The TM category originally proposed in the ISO 50001 standard is composed of a board chosen by the organization linked to the industrial area and is responsible for establishing the energy management strategy [16]. The top management of a company consists of the people who effectively make decisions involving the fate of an organization and play a key role in the management system [21].

The responsibilities of the functional area TM for the EnMS, in order of precedence and relevance are [7]:

Demonstrate commitment to support the EnMS to continuously improve its effectiveness;

Define, establish, implement, and maintain an energy policy (an energy policy refers to the organization's statement about its intentions and general guidelines related to its energy performance) [22];

Consider long-term energy strategies;

Appoint a representative and approve the formation of the energy management team;

Identify the scope and boundaries to be addressed by the EnMS (the scope refers to the scope of the EnMS, and the boundaries refer to the physical and organizational boundaries established for the EnMS);

Provide resources to establish, implement, maintain, and improve the EnMS;

Approve the energy review, objectives, energy goals, and action plans established by the EnMS;

Ensure the establishment of energy goals and targets and action plans for the EnMS (energy objectives refer to the results or achievements established to meet energy policy) [22];

Conduct managerial reviews, internal audits, and critical reviews of the EnMS to verify that the stated goals and objectives are being/will be met;

Communicate the importance of energy management to the organization.

As a form of incentive, TM may also offer rewards, bonuses, and awards to the EnMT in response to the good performance of the EnMS.

\section{Intra-organizational: FA Energy Management Team (EnMT) / Energy Manager}

The EnMT originally proposed by the ISO 50001 standard is composed of the people responsible for the effective implementation of energy management activities and the achievement of energy performance improvements. Energy management standards generally recommend the use of energy management teams, as this is the least expensive structure for the implementation and maintenance of an EnMS [7,23,24].

Initially, the Energy Manager appointed by TM selects employees from across the company to form a multifunctional team, called an EnMT. This team can be composed of elements (people) from any functional area of the organization, and the following functional categories are recommended according to the "Teaming up to Save Energy" report [25]: (i) Electrical/Mechanical engineering; (ii) Engineering and Process; (iii) Administrative/Purchasing; (iv) Financial/Accounting; (v) Operations and Maintenance; (vi) Housekeeping; (vii) Human Resources; (viii) Health and Safety; and (ix) Electrical Supervisor, as shown in Figure 2. In some industries, it is common to hire an employee responsible for the utilities, which corresponds to the management of electrical energy, gas, and water, among others. 


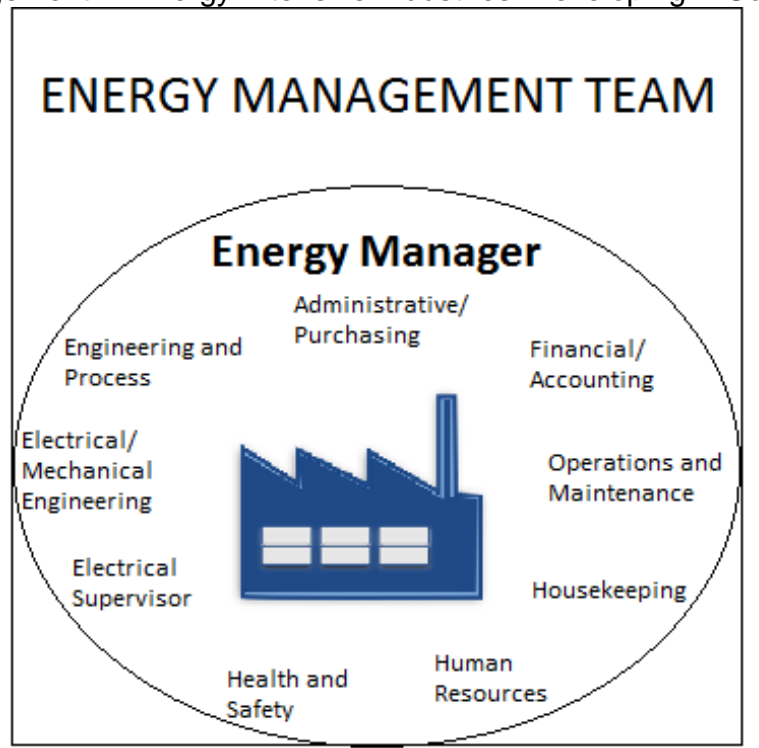

Figure 2. Suggested Energy Management Teams. Source: Adapted by the author from EPA, 2006 [25].

The EnMT, together with the energy manager, make up the EnMT/energy manager functional area.

The functions of the EnMT/energy manager in the EnMS are:

Define roles, responsibilities, positions, and authority, as well as coordinate the operation of the SGE. Such activities are the sole responsibility of the energy manager $[7,26]$.

Elaborate the work plan, incorporating the monitoring of electric energy, gas, fuel, and water bills [27,28];

Document the EnMS, including publishing an energy manual, and communicate the actions taken to the entire organization [7,27];

Conduct courses and training, as well as take action related to occupational safety and health [28]. Aspects related to occupational safety and health when dealing with the various forms of energy (electricity, heat, steam, compressed air, etc.) require special attention by public and private companies to the standards and regulations in force. In Brazil, the regulatory norms $(\mathrm{NR})$ regarding occupational safety and health are mandatory, and among them the following stand out: (i) NR10 - Safety in facilities and services in electricity; (ii) NR12 - Safety at work in machinery and equipment; (iii) NR13 - Boilers, pressure vessels, and pipelines. Failure to comply with legal and regulatory provisions will result in the penalties specified the in current legislation [29-32];

Lead the definition of goals, energy goals, and action plans [27,28];

Conduct a detailed initial energy review and develop an energy audit style that can be appropriately implemented by FA Engineering [26];

Coordinate activities related to energy certifications $[8,28,33]$. The EnMT can add to the activities of the EnMS in addition to analyzing the energy performance of production systems (where the greatest opportunities for energy efficiency are available), through energy certification activities (Leed, AQUA, etc.) for other types of energy users (e.g., buildings) in the organization. These activities aim to improve the energy performance of the facilities of the organization as a whole, demonstrating to the community, partners, and suppliers the organization's concern regarding energy issues. In Brazil, the Procel seal of energy conservation (created by the National Program for the Conservation of Electric Energy - Procel) allows the consumer to identify the most efficient and energy-consuming appliances and equipment available in the market. Likewise, the Procel Buildings stamp measures the degree of energy efficiency of Brazilian buildings [34];

Coordinate the accounting for greenhouse gas emissions (GHG) [18, 19, 24]. The accounting of greenhouse gas emissions enables improvements in the operational management and energy efficiency of a plant, where the knowledge generated by emissions 
management can serve as a basis for strategic planning, enabling improvements in administrative, operational, and financial management, as well as in the rationalization of the use of inputs and in the optimization of energy consumption in a company [35];

Coordinate energy benchmarking $[8,28,33]$. Benchmarking is the continuous process of evaluating products, processes, or services in relation to main competitors or standard market practices. That is, it defines a typical level of consumption, allowing the rapid comparison, evaluation, and identification of potential improvements. According to the Energy Star Guidelines for Energy Management, the main steps of benchmarking include: (i) determine the level of benchmarking (e.g. equipment, process line, factory, or organization); (ii) develop metrics; (iii) conduct comparisons; and (iv) monitor performance over time $[36,37]$. The benchmarking of industrial energy use, or energy benchmarking, is carried out by comparing the energy consumption of plants having similar characteristics as a function of their total production volumes, or as a function of the total number of plants operating at the same level of efficiency or lower [38]. Energy benchmarking can be used as a tool to compare the energy performance of a given company with that of its competitors to estimate the energy savings potential, favoring reductions in energy consumption and emission of GHG, and thus is an important tool for the implementation of energy efficiency programs in any type of industry [37,39-41];

Coordinate implementation/operation and verification activities, adopting measurement procedures through the International Measurement and Performance Verification Protocol (IPMVP) or specific standards, such as ISO 50015: 2014 [2,42];

Coordinate compliance with legal requirements regarding energy aspects. These are international, national, regional, and local energy requirements that apply to the scope of an energy management system. Examples of legal requirements may include a national energy conservation law or regulation. Examples of other requirements may include agreements with clients, principles or codes of good practice, voluntary programs, and others.

\section{Intra-organizational - FA Engineering}

The functional area of engineering, among other activities, has responsibilities for: (i) study; (ii) planning; (iii) project; (iv) specification; (v) execution; (vi) installation; (vii) assembly; and (viii) inspection of processes and systems involving various specialized techniques (electrical, mechanical, production, civil, environmental, etc.).

Engineering with regard to the SGE must carry out a fundamental step for the implementation of the proposed energy management system, which is the implementation of the energy revision process.

The energy review, also called energy auditing or energy diagnosis, is a "key process" that opens the door for the organization to analyze the use and energy consumption of its facilities, identify areas of significant energy use, determine their current energy performance, estimate future energy use and consumption, and identify and record existing energy performance improvement opportunities. The information obtained in the energy review stage is fundamental to the later phases of the EnMS, and will help in the establishment of the energy baseline, in the identification of energy performance indicators (EnPI), and in the definition of the objectives, goals, and actions needed to implement the EnMS [7].

Initially, engineering should check the need to hire an ESCO to support energy review activities. If there is no need to hire an ESCO, engineering must assume the responsibility of performing the energy review (ER).

It is also the responsibility of engineering to analyze and define which simulators (software tools) are adequate to assist in the diagnosis, modeling, and statistical analysis of the energy system(s) where the EnMS will be implemented.

Simulators are computational tools used as aids in energy planning, in searching for energy efficiency opportunities, and in the realization of efficiency projects [2].

Software tools can be made available free of charge by government entities in countries that have developed energy management systems (Japan, the United States, Denmark, Brazil, and the United Kingdom, among others), among which are the Department of Energy 
(DOE) Advanced Manufacturing Office (AMO) and Energy Star in the United States, and Procel (National Program for the Conservation of Electric Energy) in Brazil. Such computational tools can also be developed and marketed by private companies active in the area of energy performance improvements for organizations.

Among the simulators that can be applied to industries made available by the DOE AMO in the United States, are [43]:

AIRMaster+: Online tool that assists in the analysis of energy use and allows identifying opportunities for improvement in compressed air industrial systems;

Energy Performance Indicator Tool: Analysis tool that allows establishing an energy consumption baseline, as well as mapping the annual progress of improving energy efficiency in industrial plants;

Fan System Assessment Tool: Online tool that allows evaluation of the energy consumption and identification of opportunities for improvements in industrial ventilation systems.

Among the simulators provided by PROCEL having applications in the industry, the following stand out [44]:

BDmotor: Program for evaluation of comparison and sizing of electric motors;

DiaLUX: Software for lighting calculations, allowing the evaluation of the energy efficiency of lighting systems in residential, commercial, and industrial buildings;

Domus hygrothermal and energy simulation software for buildings (commercial and industrial).

During the construction of an energy management system, areas of specialization are necessary, such as electrical and mechanical engineering, as well as production/product engineering, in order to carry out the necessary work associated with implementing the system.

The functional engineering area, specializing in the field of electrical engineering, is in charge of evaluating the supply of electricity in the form of the supply contract with the local energy concessionaire(s). If the company acquires energy in the free market, the contracts with the electric energy marketer(s) should be reviewed [14]. In these contracts, risks and security of supply should be assessed and predicted, and if possible, the renegotiation of prices and tariffs should be sought.

Analysis of the energy supply of large industries imposes the need for the installation of electronic measurement and monitoring systems (MT\&R), evaluation of the quality of energy used, management of utilities (water, gas, fuels), and quantifying environmental parameters.

MT\&R's are devices capable of measuring and monitoring the various forms of energy consumed by the plant, performing measurements in real time, fully supported by online resources. In case the organization does not have such support, the engineering functional area should report this situation to the energy manager and ask the purchasing department to purchase the necessary tools.

To provide automatic real-time analyses of energy consumption and utilities in industrial facilities, MT\&R's operate in conjunction with proprietary and non-proprietary software that monitors existing processes to enable verification of the evolution of energy consumption over time.

The use of MT\&R's allows:

Accurate monitoring of consumption and corresponding costs for energy;

Avoidance of any fines related to exceeding consumption in demand-based contracts;

Measuring electrical parameters (voltage, current, frequency, power consumed, and power factor, among others);

Assessing the quality of energy;

Quantifying and managing emissions of pollutants and waste (environmental parameters);

Precisely quantifying energy consumption by sector (sectoral measurement).

The sectoral measurement refers to the individual measurement (sub-metering) of the energy consumption of each unit or process in the plant, either for the purpose of apportionment of consumption, assigning the correct portion of energy consumption to each 
cost center, or for the purpose of sectorial verification of indexes essential to understand the variations in daily and annual energy consumption.

Some of the electronic measurement and monitoring systems available on the market can perform sector measurements if installed individually on the electrical panels that power the various processes or plant units. Thus, it is possible to identify and monitor the sectors that have the highest energy consumption (which may require special attention when taking actions to improve energy efficiency), and to monitor the evolution of the energy consumption resulting from any remedial actions taken.

According to [6], "a monitoring system that uses sector-level measurement at the plant level is one of the key prerequisites for proper allocation of energy costs and adoption of a successful energy management system."

From the data and measurements obtained by MT\&Rs, it is possible to analyze the use and consumption of energy in the plant. Such analyses should be performed by the engineering functional area specializing in the field of electrical engineering, through energy balances, Pareto graphs, or risk analyses and cost priorities to identify significant energy use and energy efficiency opportunities existing in the plant.

After analyzing the energy supply, the feasibility of distributed generation and cogeneration is evaluated for the plant. Distributed Generation (DG) is the term used to designate the generation of electric energy in a decentralized manner, carried out next to or near the area where the energy will be used, and is regulated in Brazil through decree $\mathrm{n}^{\circ}$ 5.163 / 04 [45]. DG encompasses various generation technologies: (i) solar; (ii) wind; (iii) hydroelectric power with a power of less than or equal to $30 \mathrm{MW}$; (iv) thermoelectric plant with an efficiency greater than or equal to $75 \%$; $(v)$ thermoelectric plant that uses biomass or process residues as fuel; and (vi) energy storage. Within the scope of the distributed generation domain, one can include the storage of energy in its various forms, such as batteries, capacitors, and flywheels.

The engineering functional area specializing in mechanical engineering should analyze the supply of gas and other relevant fuels, focusing on supply contracts (involving safety analysis and risks in energy supply). The search for renegotiations in the prices of these inputs is also part of the responsibilities of the mechanical engineering team [14].

In addition, the mechanical engineering team should evaluate the significant consumption of gas, steam, heat, and compressed air, using spreadsheets and other available tools (software tools similar to those used by the electrical engineering team). At this stage, the possibility of installing cogeneration systems should also be evaluated.

Energy cogeneration is a process that combines the generation of heat and electricity, which increases the utilization of the energy contained in the fuels used in this process. The most commonly used cogeneration systems are gas or steam turbines, internal combustion engines, recovery boilers, and heat exchangers.

In conventional thermal generation systems, approximately sixty-five percent of the energy contained in (usually fossil) fuels is dissipated as heat, and only thirty-five percent is actually converted into electrical energy. When implementing a cogeneration system using heat, it is possible to convert up to eighty-five percent of the energy contained in the fuels into useful energy.

The use of cogeneration systems allows the combination of economic and environmental benefits by generating electricity and heat at low cost with low losses, high reliability, and low GHG emissions.

During ER realization, the engineering functional area may also involve production / process engineering to report opportunities for loss minimization in industrial processes and optimization possibilities. Production engineering can still be responsible for the Life Cycle Analysis - LCA.

According to ISO 14040 [46], LCA is a technique for assessing environmental aspects and potential impacts throughout the life cycle of a product, from the acquisition of raw materials through production and use ("from cradle to grave "). LCA assists in identifying opportunities for improvements in product environmental aspects throughout a product's life cycle, in industry decision-making, in the selection of environmental performance indicators 

(including measurement techniques), and in marketing. The use of the LCA also allows the evaluation of the inputs and the results of the individual processes throughout the plant, so that the energy efficiency processes and projects are coordinated with the energy objectives and goals (energy planning) of the EnMS[1].

\section{Intra-organizational - FA Maintenance}

The functional area of maintenance is of fundamental importance in the operation and management of energy in the industry. According to [47], an efficient maintenance team can generate great savings by reducing energy losses, as well as by avoiding additional costs arising from the need to replace equipment as a result of breakage (preventive and predictive maintenance).

In this study, the maintenance functional area was divided into two areas of specialties: electrical and mechanical. However, depending on the type, needs, and characteristics of each industry, this functional area can be subdivided in different ways.

Mechanical maintenance is responsible for industrial processes involving heat, steam, compressed air, and gas, while electrical maintenance is responsible for the operation and maintenance of electrical power systems, such as transforming substations, power distribution boards, etc. The electrical specialty is also responsible for the daily monitoring of the data obtained by electronic measurement and monitoring systems - MT\&Rs.

It is the responsibility of the functional area to maintain, in addition to routine corrective, preventive, and predictive interventions, tasks such as verification of operational conditions and identification of energy losses in their most diverse forms in plant equipment. This situation requires specific maintenance tools for the EnMS.

These maintenance tools have two basic functions: to assist in the verification of operating conditions and in the online monitoring of equipment [47]. The instruments are classified according to the quantities they measure and the operational abnormalities detected in devices and equipment, such as trepidations variations in speed, pressure, temperature, and electrical parameters, among others. In terms of energy efficiency, instruments capable of detecting energy losses such as voltage drops, electric current leaks, and compressed air, steam, gas, water, and heat leaks are relevant [48]. The maintenance instruments used for energy management in the industry are listed in Table 1. 
Table 1 - Maintenance Tools

\begin{tabular}{|c|c|c|}
\hline System & Instrument & Measured Parameter \\
\hline $\begin{array}{ll}\text { Civil } & \text { structure } \\
\text { (envelope) } & \\
\end{array}$ & Thermovisor & Heat loss \\
\hline $\begin{array}{l}\text { Steam and water } \\
\text { heating }\end{array}$ & Thermometer & Temperature \\
\hline \multirow{6}{*}{$\begin{array}{l}\text { Heating, Ventilation } \\
\text { and Air Conditioning }\end{array}$} & Stethoscope & Noise \\
\hline & Flow Hood and Pitot Tube & Air flow \\
\hline & Bourdon tube and tube & Pressure \\
\hline & Thermometer & Temperature \\
\hline & Hole Flow Meter & Air or vapor flow \\
\hline & Psychrometer & Humidity \\
\hline \multirow[b]{2}{*}{ Eletric } & $\begin{array}{l}\text { Multimeter pliers; wattmeter; } \\
\text { power factor meter }\end{array}$ & $\begin{array}{l}\text { Voltage, current and ohmic resistance; active power } \\
\text { consumed; power factor }\end{array}$ \\
\hline & $\begin{array}{|lc|}\text { Power } & \text { Quality } \\
\text { Analyzer/Multifunction } & \text { Power } \\
\text { Meter (Power Analyzer) } & \\
\end{array}$ & $\begin{array}{l}\text { Electrical power (apparent, active, and reactive), } \\
\text { power factor, voltage, current, frequency, harmonic, } \\
\text { transient distortions, among other magnitudes }\end{array}$ \\
\hline Lighting & Industrial Lux meter & Illumination \\
\hline \multirow{3}{*}{ Air Compressors } & Pressure gauge & Oil and air pressure \\
\hline & Stethoscope and infrared camera & Bearing wear \\
\hline & Strobe & Vibration \\
\hline
\end{tabular}

Source: The Author.

\section{Intra-organizational - Production}

The functional area of production is one of the central areas of an organization, because it produces the goods and services that are the reason for its existence [49].

Production, in addition to its routine assignments, such as strategy and production planning, product and service design, production systems, study of timing and movement, productive arrangements, ergonomics, etc., is also pertinent to an energy management system and is used to analyze, when necessary, the optimization of industrial processes [48].

The optimization of industrial processes refers to the continuous improvement of all process steps to improve local and global performance indices, maximize productivity and safety, and minimize operational costs.

Improving the energy efficiency of a system or process is an essential step in controlling energy consumption and energy costs [50].

Optimization activities should involve the following industrial systems at a minimum, where they exist: (i) electrical; (ii) heat; (iii) steam; (iv) compressed air; and (v) gas.

\section{Intra-organizational - Administration}

The functional area of the administration acts in the planning, organization, management, and control of the organization. It is the functional area responsible for publicizing the creation of the energy management team to the entire company. 
The functions of the administration's functional area, regarding energy issues, are related to the activities of:

Human Resources: Hiring qualified professionals to carry out education (training) and ensure the occupational safety and health of the organization's employees [28];

Purchasing: Professionals with sufficient technical qualifications to specify and manage the contracts involving purchase of energy and equipment for the EnMS [7,14,51]; [26,34];

General services (Housekeeping) in buildings (electrical, hydraulic, among others)

Management of the fleet of vehicles for energy performance optimization purposes: electric vehicles, hybrids, and use of alternative fuels (fuel cells, biodiesel, and ethanol, among others).

\section{Elaboration of the Conceptual Map}

When mapping the process of energy management, it was verified that a structured spider map is the most appropriate to explain the relationships among the actors (external organizations and intra-organizational areas) involved in the energy management system proposed, although the use of this structure implies a greater complexity for the connection (understanding) of the concepts among the different functional areas involved in the EnMS.

Figure 3 generically illustrates an example of a spider conceptual map.

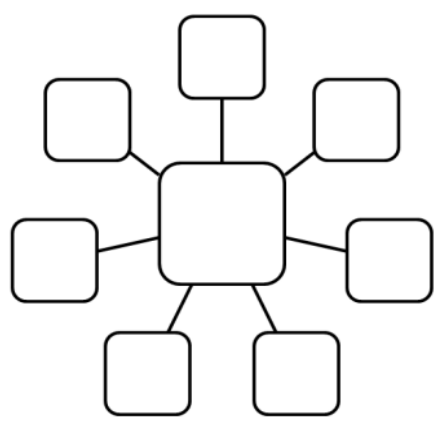

Figure 3. Structured Spider Map.

Source: Adapted from Novak and Cañas, 2006 [9]

The complete conceptual map, Figure 4, which agglomerates and makes explicit the relationships among the intra-organizational functional areas and external organizations involved in the energy management process for the Ell's is presented in Appendix A of this paper.

\section{DISCUSSION}

The present work was designed to meet the main requirements of ISO 50001, including defining the roles and responsibilities of the bodies involved in the EnMS. Thus, a board is defined as "senior management" that will be responsible for the implementation of the EnMS and selection of an EnMT. The EnMT adopts an "ad hoc" organizational structure format, with work shared by employees from various areas of the organization, led by an energy manager who is responsible for conducting this process.

This structure creates difficulties in conducting an efficient energy management system with regard to problems related to authority, responsibilities, etc. However, this organizational structure is less burdensome to an organization compared to a formal, departmental structure established for the sole purpose of energy management (formally established bodies with the sole purpose of conducting energy management in an industry).

The other internal areas of an industrial company mostly involved with energy management activities were determined by their affinity and relationship with energy issues. These areas are: functional areas of engineering, maintenance, production, and administration. 
The presentation of the conceptual map considers the hierarchy of responsibilities for the EnMS, so that the actors with the greatest responsibilities are presented at the top of the map (functional areas with managerial assignments: Top Management, EnMT/Energy Manager, and Administration) and the actors with lower responsibilities at the bottom of the map (functional areas with technical assignments, functions related to the factory floor: engineering, maintenance, and production).

The actions and attributes of the actors involved in the EnMS were presented in the conceptual map in order to meet the plan-do-check-act (PDCA) cycle provided in ISO 50001, following a logical chain, having as criteria for the order of presentation the level of importance of each action for the EnMS (greater weight), and chronological order of precedence for actions (lower weight).

\section{CONCLUSION}

The first specific objective was met with the creation of a basic diagram of an EnMS. The basic diagram was developed according to the ISO 50001 standard for successful practices of energy management and process design.

The second objective of data categorization described the main actors/stakeholders in an arrangement based on external organizations and internal actors (intra-organizational).

In order to meet the third objective for constructing the conceptual map, a spider map was elaborated because it is the most adequate to represent the way the proposed EnMS evolves (how external and internal organizations relate to one another). On the other hand, this structure implies a greater complexity for the connections (interconnections) of the concepts of the different functional areas involved in the EnMS. However, the spider map can be appropriately arranged to allow a full understanding of the concepts involved.

The conceptual map developed represents an EnMS for the Ell in a clear (conceptually and visually), orderly, unified, harmonious, and balanced distribution of its elements, functioning as an initial step in the creation of an ontology for this area of knowledge.

As a limitation of the research, the fact that because of the complexity involved in the analysis, some functional areas that participate in the energy management process (although with less intensity, such as legal, accounting / financial and marketing) were not considered in this study. Such functional areas can be incorporated into the study in future work.

As a further suggestion, mapping specific industry types or companies can be performed to better understand the various concepts involved.

The present work was carried out with the support of the Coordination of Improvement of Higher Education Personnel - Brazil (CAPES) - Financing Code 001.

\section{REFERENCES}

1. SolarPower Europe Aflaki, S.; Kleindorfer, P. R.; PolvorinoS, V. S. M. Finding and Implementing Energy Efficiency Projects in Industrial Facilities. Production and Operations Management, v. 22, n. 3, p. 503-517, 2013.

2. Bunse, K.; Vodicka, M.; Schönsleben, P.; Brülhart, M.; Ernst, F. Integrating energy efficiency performance in production management: gap analysis between industrial needs and scientific literature. Journal of Cleaner Production, ed. 19 (2011), p. 667-679, 2011.

3. Cagno, E. et al. A novel approach for barriers to industrial energy efficiency. Renewable and Sustainable Energy Reviews, v. 19, p. 290-308, 2013.

4. Groot, H. L. F., Verhoef, E.T, Nijkamp, P. Energy Saving by firms: decision-making, barriers and policies. Energy Economics, v. 23, p. 717-740, 2001.

5. Sorrell S. et al., 2000. Barriers to Energy Efficiency in Public and Private Organizations - final report. SPRU 2000.

6. Thollander, P.; Ottosson, M. Energy management practices in Swedish energy-intensive industries. Journal of Cleaner Production, v. 18, n. 12, p. 1125-1133, 2010.

7. Associação Brasileira de Normas Técnicas. NBR ISO 50001:2011 - Sistemas de Gestão de Energia - Requisitos com orientações para uso. Rio de Janeiro, 2011. 
Energy Management In Energy-Intensive Industries: Developing A Conceptual Map

8. Silva, V. R. R. G.; Loures, E. F. R.; Lima, E. P.; Costa, S. E. G. Gestão da Energia na Indústria: Uma Abordagem de Engenharia Organizacional. Smart Energy CIEI \& EXPO 2017, Curitiba, 2017.

9. Novak, J. D.; Cañas, A. J. The Theory Underlying Concept Maps and How to Construct and Use Them. Technical Report IHMC CmapTools 2006-01, Rev 01-2008, Florida Institute for Human and Machine Cognition, 2008.

10. Plotnik, E. Concept Mapping: A Graphical System for Understanding the Relationship between Concepts. ERIC Digest, 1997.

11. Inspiration Software. (1994). Inspiration for windows: User's manual [computer program manual]. Portland, OR: Author.

12. MindMeister. Available in: <https://www.mindmeister.com/pt/>. Acess date: 28/10/2017.

13. Câmara de Comercialização de Energia Elétrica - CCEE. Ampliação do mercado livre de energia elétrica. Dezembro, 2014.

14. Vine, E. An International Survey of the Energy Service Company (ESCO) Industry. Energy Policy, ed. 33 (2005), p. 691-704, 2005.

15. Sorrell, S. The economics of energy service contracts. Energy Policy, v. 35, n. 1, p. 507-521, 2007.

16. ABRADEE - Associação Brasileira de Distribuição de Energia Elétrica. Glossário do Setor Elétrico. Available in: <http://www.abradee.com.br/setor-eletrico/glossario-do-setor-eletrico>. Acess date: 11/08/2017.

17. ABRACEEL - Associação Brasileira de Comercializadores de Energia. Mercado Livre de Energia Elétrica: Guia básico para consumidores potencialmente livres e especiais. 2016. p. 15.

18. Abesco - Associação Brasileira das Empresas de Serviços de Conservação de Energia. Available in <http://www.abesco.com.br/pt/>. Acess date: 11/08/2017.

19. Fang, W. S.; Miller, S. M.; Yeh, C. C. The Effects os ESCOs on Energy Use. Energy Policy, ed. 51 (2012), p. 558-568, 2012.

20. Dobes, $V$. New tool for promotion of energy management and cleaner production on no cure, no pay basis. Journal of Cleaner Production, v. 39, p. 255-264, 2013.

21. ABNT NBR ISO 9000 - Sistemas de gestão da qualidade - Fundamentos e vocabulário. Associação Brasileira de Normas Técnicas, Setembro, 2015.

22. Fawkes, S.; Oung, K.; Thorpe, D. Best Practices and Case Studies for Industrial Energy Efficiency Improvement - An Introduction for Policy Makers. Copenhagen: UNEP DTU Partnership, 2016. 171p.

23. American National Standards Institute. ANSI/MSE 2000:2008 - A Management System for Energy. 2008.

24. Cen - European Committee for Standardization. EN 16001:2009. Energy Management system requirements with guidance for use. November, 2009.

25. U.S. EPA. United States Environmental Protection Agency. 2006. Teaming Up to Save Energy. Washington, D.C.: Climate Protection Division, Report 430-K-05-007.

26. Abdelaziz, E. A.; Saidur, R.; Mekhilef, S. A review on energy saving strategies in industrial sector. Renewable and Sustainable Energy Reviews, v. 15, n. 1, p. 150-168, 2011.

27. Ates, S. A.; Durakbasa, N. M. Evaluation of corporate energy management practices of energy intensive industries in Turkey. Energy, v. 45, n. 1, p. 81-91, 2012.

28. Schulze, M. et al. Energy management in industry - a systematic review of previous findings and an integrative conceptual framework. Journal of Cleaner Production, v. 112, p. 3692-3708, 2016.

29. Brasil. Ministério do Trabalho e Emprego. NR 10 - Segurança em instalações e serviços em eletricidade. Ministério do Trabalho e Emprego. Available in: <http://trabalho.gov.br/images/Documentos/SST/NR/NR10.pdf>. Acess date: 30/01/2018.

30. BRASIL. Ministério do Trabalho e Emprego. NR 13 - CALDEIRAS, VASOS DE PRESSÃO E TUBULAÇÃO. Ministério do Trabalho e Emprego. Available in: $<$ http://trabalho.gov.br/images/Documentos/SST/NR/NR13.pdf>. Acess date: 30/01/2018.

31. BRASIL. Ministério do Trabalho e Emprego. Normas Regulamentadoras, 2015. Available in: <http://trabalho.gov.br/seguranca-e-saude-no-trabalho/normatizacao/normas-regulamentadora s>. Acess date: 12/10/2017. 
32. BRASIL. Ministério do Trabalho e Emprego. NR 12 - SEGURANÇA NO TRABALHO EM MÁQUINAS E EQUIPAMENTOS. Available in:

$<$ http://www.trabalho.gov.br/images//Documentos/SST/NR/NR12/NR-12.pdf>. Acess date: 30/01/2018.

33. Worrell, E. et al. Industrial energy efficiency and climate change mitigation. Energy Efficiency, v. 2, n. 2, p. 109-123, 2008.

34. Procel. Selo Procel, 2006. Available in:

<http://www.procelinfo.com.br/main.asp?TeamID=\%7B88A19AD9-04C6-43FC-BA2E-99B27EF $54632 \% 7 \mathrm{D}>$. Acess date: 12/10/2017.

35. ABNT NBR ISO 14064. Gases de Efeito Estufa. Associação Brasileira de Normas Técnicas, Novembro, 2007.

36. Doe. Energy Star Program. Available in: <https://www.energystar.gov/index.cfm?c=about.ab_history>. Acess date: 11/10/2017.

37. Energy Star. Energy Star Guidelines for Energy Management, 2017.

38. Unido. Global Industrial Energy Efficiency Benchmarking - An Energy Policy Tool Working Paper. United Nations Industrial Development Organization, Austria, November, 2010.

39. Boyd, G.; Dutrow, E.; Tunnessen, W. The evolution of the ENERGY STAR $®$ energy performance indicator for benchmarking industrial plant manufacturing energy use. Journal of Cleaner Production, v. 16, n. 6, p. 709-715, 2008.

40. Chan, D. et al. Energy efficiency benchmarking of energy-intensive industries in Taiwan. Energy Convers Manag, 77, 216-220, 2014.

41. Saygin, D.; Worrell, E.; Patel, M.K.; Gielen, D.J. Benchmarking the energy use of energy-intensive industries in industrialized and in developing countries. Energy, ed. 36 (11), p. 6661-6673, 2011.

42. ISO 50015. Energy management systems - Measurement and verification of energy performance of organizations - General principles and guidance. International Organization for Standardization, Geneva, Switzerland, Dec., 2014.

43. Office of Energy Efficiency \& Renewable Energy - EERE. Software Tools. Available in: $<$ https://energy.gov/eere/amo/software-tools>. Acess date: 30/01/2018.

44. Procel. Simuladores. Available in: $<$ http://www.procelinfo.com.br/main.asp?TeamID=\{796B68CB-2559-401F-A481-DC3D145F57 2E\} $>$. Acess date: 12/10/2017.

45. BRASIL. Presidência da República. Casa Civil, Subchefia para Assuntos Jurídicos. Decreto no 5.163 de 30 de Julho de 2004.

46. ABNT NBR ISO 14040 - Gestão ambiental - Avaliação do ciclo de vida - Princípios e estrutura. Associação Brasileira de Normas Técnicas, Novembro, 2001.

47. Turner, W.C.; Doty, S. Energy Management Handbook. ed. 6, The Fairmont Press, 2007.

48. Capehart, W.; Turner, W.C.; Kennedy, W.J. Guide to Energy Management. ed. 4, The Fairmont Press and Marcel Dekker Inc., 2003.

49. Slack, Nigel; Chambers, Stuart; Johnston, robert. Administração da Produção: Atlas, ed. 2, 2002.

50. Giacone, E.; Mancò, S. Energy efficiency measurement in industrial processes. Energy, v. 38, n. 1, p. 331-345, 2012.

51. Price, L.; Wang, X.; Yun, J. The challenge of reducing energy consumption of the Top-1000 largest industrial enterprises in China. Energy Policy, v. 38, n. 11, p. 6485-6498, 2010.

(C) 2018 by the authors. Submitted for possible open access publication under the terms and conditions of the Creative Commons Attribution (CC BY NC) license (http://creativecommons.org/licenses/by-nc/4.0/). 


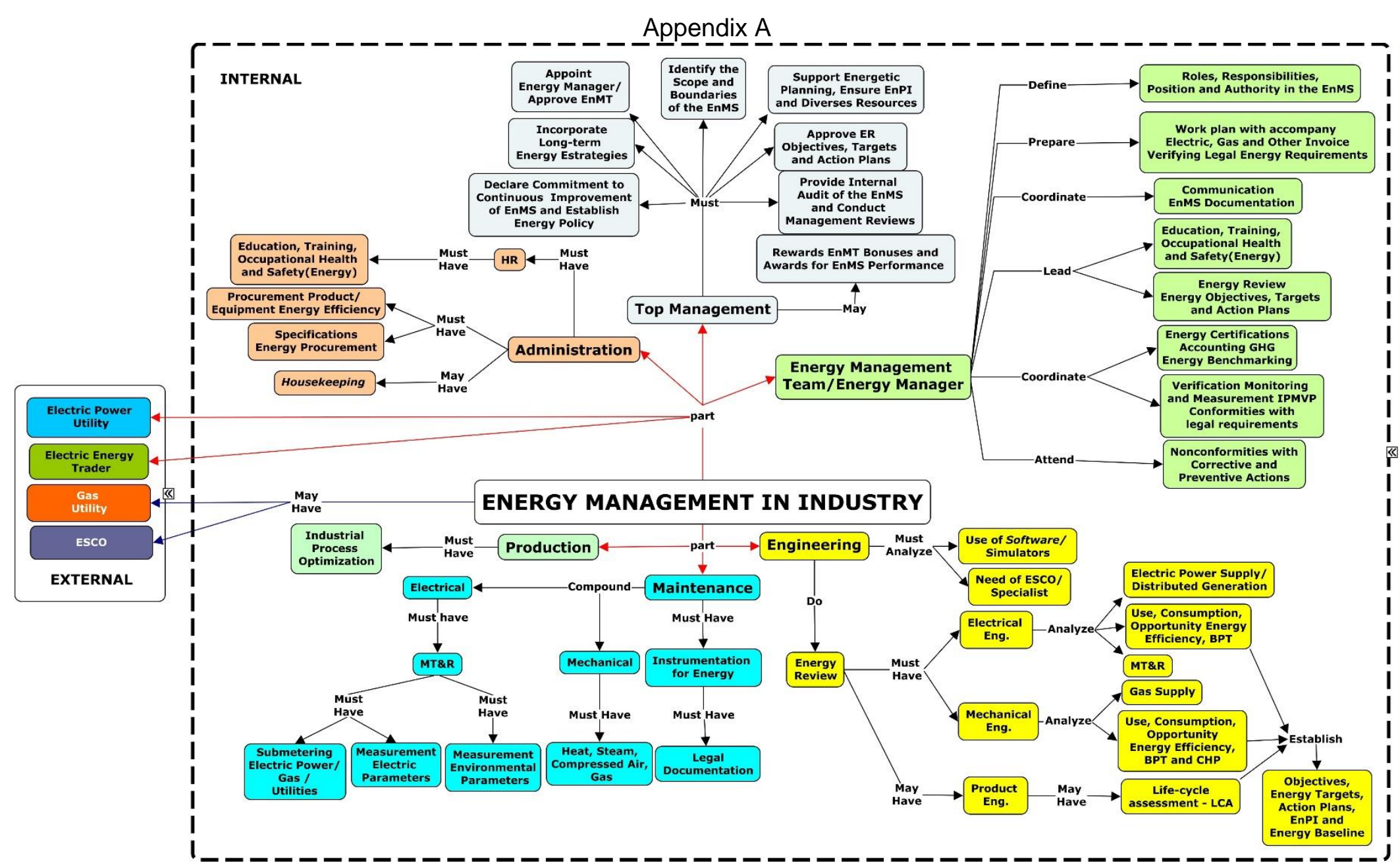

Figure 4. Conceptual Map for an Energy Management System in an Industrial Company.

Source: The Author, 2018 